\title{
Biosecurity policy and legislation of the seaweed aquaculture industry in Tanzania
}

\author{
Sadock B. Rusekwa ${ }^{1}$ - Iona Campbell ${ }^{2}$. Flower E. Msuya ${ }^{1}$ (D) Amelia S. Buriyo ${ }^{1} \cdot$ Elizabeth J. Cottier-Cook $^{2,3}$
}

Received: 20 March 2020 / Revised and accepted: 12 May 2020 / Published online: 7 August 2020

(C) The Author(s) 2020

\begin{abstract}
Pest and disease outbreaks have significant impacts on the livelihoods of seaweed farmers each year, particularly in low- to middle-income countries around the world. Commercial seaweed farming of the red carrageenophytes, Eucheuma denticulatum, Kappaphycus alvarezii and Kappaphycus striatus, in Tanzania was established in 1989. The impacts of pests and diseases on the local seaweed industry had serious implications for the environment, society, local culture and human health. The industry was initially characterised by growth, but since 2002 has been severely limited due to pest and disease outbreaks, exacerbated by the effects of climate change. This paper identifies existing biosecurity frameworks in Tanzanian legislation and policies in order to assess their content regarding the management of pests and diseases in the seaweed industry. A total of thirteen frameworks were identified and analysed for their general biosecurity scope and inclusion of specific risks. Of the thirteen, only four were legally binding, and only four were identified to be applicable to the seaweed industry. National frameworks were predominantly designed to support finfish aquaculture; therefore, national authorities lack the expertise, experience and scientific basis on biosecurity issues in seaweed industry compared with other aquatic commercial commodities to identify and mitigate the risks from pest and disease outbreaks in the seaweed farming industry. Recommendations are provided to assist regulators in establishing biosecurity policies, which either explicitly include or are specifically designed, to support the Tanzanian seaweed industry. This analysis reveals where biosecurity capacity can be developed to support a sustainable and economically productive national seaweed farming industry.
\end{abstract}

Keywords Biosecurity $\cdot$ Diseases $\cdot$ Pests $\cdot$ Legislation $\cdot$ Policy $\cdot$ Tanzania

\section{Introduction}

The cultivation of red, carrageenophyte seaweeds Eucheuma denticulatum, Kappaphycus alvarezii and Kappaphycus striatus was established in Tanzania in 1989 (Lirasan and Twide 1993; Mshigeni 1998; Lyimo et al. 2006; Msuya 2010, 2017) using imported strains from the Philippines (Msuya 2005). It has been actively supported by the government and academia since 1996, through improvements in farming techniques and the provision of advice to help

Elizabeth J. Cottier-Cook

Elizabeth.Cottier-Cook@uhi.ac.uk

1 Botany Department, University of Dar es Salaam, Dar es Salaam, United Republic of Tanzania

2 The Scottish Association for Marine Science (SAMS), Scottish Marine Institute, Argyll, UK

3 Association for Marine Science, University of the Highlands and Islands, Oban PA37 1QA Argyll, UK empower the farmers (Msuya 2010). Seaweed farming is also not only a direct source of income to the farmers, but it indirectly supports approximately 31,000 farmers living on the coast of Tanzania (Msuya et al. 2014), although information on farmers at the family unit is lacking. The industry has become particularly important for women in the community, who typically manage the farms (Eklöf et al. 2012; Msuya 2012; Cai et al. 2013; Valderrama et al. 2013; Msuya and Hurtado 2017). Their personal income from seaweed farming contributes to an increase in the living standards of their households, enabling them to buy clothes and food for dependents, pay for their children's schooling and generally improve the quality of their living standards (Msuya 2011b; Msuya and Hurtado 2017). Most males are not engaged in seaweed farming due to low prices of the seaweed, although men would produce more seaweed because they have more energy and time to conduct the activity. In addition, seaweed farmers have been able to use their income to process the seaweed crop themselves and sell it as a value-added product. For example, since 2006, the Zanzibar Seaweed Cluster 
initiative (ZaSCI) trains farmers on how to make various seaweed value-added products, mainly food and cosmetics. ZaSCI has links with other stakeholders including the government, NGOs, UN bodies, academia and other seaweed exporters to advance these value addition activities (Msuya 2011a, 2013; Degenhardt 2015; Msuya and Hurtado 2017; Hassan and Othman 2019). Members of ZaSCI are now producing seaweed value-added products from over 20 villages including Paje, Bweleo, Bwejuu, Kidoti, Makangale and Mkoani in Zanzibar and Bagamoyo in the mainland Tanzania.

The economic benefits of seaweed production saw the Tanzanian industry grow steadily from 808 tonnes in dry weight (dw) in 1990 to $15,000 \mathrm{t} \mathrm{dw}$ in 2012. Since 2012, however, the annual production declined to 10,000 $\mathrm{t} \mathrm{dw}$ in 2018 (Department of Marine Resources Zanzibar 2019). This decline was attributed to a multitude of factors, including climate change-induced stress, which increased water temperatures in the hot season from below $30{ }^{\circ} \mathrm{C}$ in the 1990 s to $38{ }^{\circ} \mathrm{C}$ in 2009 (Hayashi et al. 2010; Msuya 2011b; Msuya and Porter 2014) and was associated with disease outbreaks, such as "ice-ice" (Msuya 2011b; Cottier-Cook et al. 2016). Coupled with the pressure of disease outbreaks, farmers have also faced the additional challenge of epiphytic filamentous algae (EFA) (Msuya and Porter 2014). Globally, the most commonly observed EFAs are Polysiphonia/Neosiphonia consortium (Hayashi et al. 2010; Eklöf et al. 2012; Msuya and Porter 2014; Valderrama et al. 2015; Msuya 2017; Ward et al. 2019; Largo et al. 2020). The EFA can either grow on top of or penetrate the surface of the seaweed thallus (Ingle et al. 2018; Largo et al. 2020), causing the disintegration of the crop tissue and degradation of crop quality. Such epiphytes can wipe out the whole seaweed industry. In some parts of Tanzania, the decrease of production due to EFAs has been observed, e.g. in Songo Island from $423.9 \mathrm{t}$ in 2003 to $26 \mathrm{t}$ in 2008 (Msuya and Porter 2014). This massive decline is thought to have been exacerbated by the outbreaks of EFAs which reduced expected harvest and caused some farmers (especially men) to stop seaweed farming.

In Zanzibar, Tanzania, seaweed production of Kappaphycus was severely affected by EFA and disease outbreaks, such that the production decreased from $1048 \mathrm{t}$ in 2008 to $16.5 \mathrm{t}$ dw in 2010 (Msuya 2011b). Production of E. denticulatum has also been observed to decrease, from $9500 \mathrm{dw}$ in 2003 to $7000 \mathrm{t} \mathrm{dw}$ in 2005 (Msuya 2013; Msuya et al. 2014). Most farmers opt to grow Eucheuma denticulatum which is resistance to diseases (ice-ice) and epiphyte attack (Msuya 2005). Another example is Madagascar where an epiphyte outbreak led to the decrease in production of $K$. alvarezii from $1860 \mathrm{tdw}$ in 2010 to only 110 dw in 2012 (Msuya et al. 2014).

The increasing frequency of disease and pest outbreaks has led to a decline in seaweed farming productivity (Msuya 2011b; Msuya and Porter 2014; Cottier-Cook et al. 2016; Largo et al. 2020), which has been negatively impacting farmers' personal income and family livelihood (Msuya 2011a), and has threatened the empowerment of the female farmers in society (Msuya 2013). In addition, recent low and unpredictable prices for seaweed have forced farmers to seek employment in other sectors (Hassan and Othman 2019). The increasing trend in outbreaks of pests and disease in Tanzania is synonymous with the growing global concern for their collective impacts on the industry over the last decade (CottierCook et al. 2016; Hurtado et al. 2017; Ward et al. 2019).

In order to limit the impacts of pests and disease in an industry, the biosecurity approach to managing risks has been widely adopted across agriculture and aquaculture. It is broadly defined as: "a strategic and integrated approach that encompasses the policy and regulatory frameworks (including instruments and activities) for analysing and managing relevant risks to human, animal and plant life and health, and associated risks to the environment" (FAO 2007). Biosecurity legislation and policies have been introduced and their measures incorporated into the management of farms across many aquaculture sectors (Rodgers et al. 2015; Stentiford et al. 2017). However, the seaweed aquaculture industry has been slow to adopt this approach (Cottier-Cook et al. 2016) and it is poorly integrated into policy and legislation at both the international and national scales (Campbell et al. 2019a; Kambey et al. 2020).

In Tanzania, biosecurity policy and practice is governed through the United Republic of Tanzania, which is composed of two main governmental bodies: one governing mainland Tanzania and the other governing the semi-autonomous region of the Zanzibar Islands. As a consequence, there are two governments: one catering for the governmental union (Government of Tanzania, GoT) and one for Zanzibar (Revolutionary Government of Zanzibar (RGoZ)) (Fig. 1). For the case of Zanzibar, the GoT controls only matters related to the union (e.g. home affairs and military operations), while RGoZ, as an autonomous government, controls matters that are specifically for Zanzibar, such as education, health and industries such as fisheries and aquaculture. Both governments have their own ministries, and thus have separate policies, although the names of the ministries are similar (e.g, both have a Ministry of Agriculture, Natural Resources, Livestock and Fisheries). The two Ministries of Agriculture, through their respective Departments of Marine Aquaculture, are responsible for developing draft policies that are approved by their respective parliaments, before implementation across the seaweed industry. In both departments, plant quarantine and phytosanitary measures already exist, in order to control plants or plant products introduced to the country or exported (GoT 1998). However, to date, a majority of biosecurity policies have been developed for the capture fisheries and finfish aquaculture sectors (GoT 2015a). Both governments have shown recent interest in developing policies to assist in the development of the seaweed industry in the region. As part of this support for aquaculture sectors, a broader aquaculture 


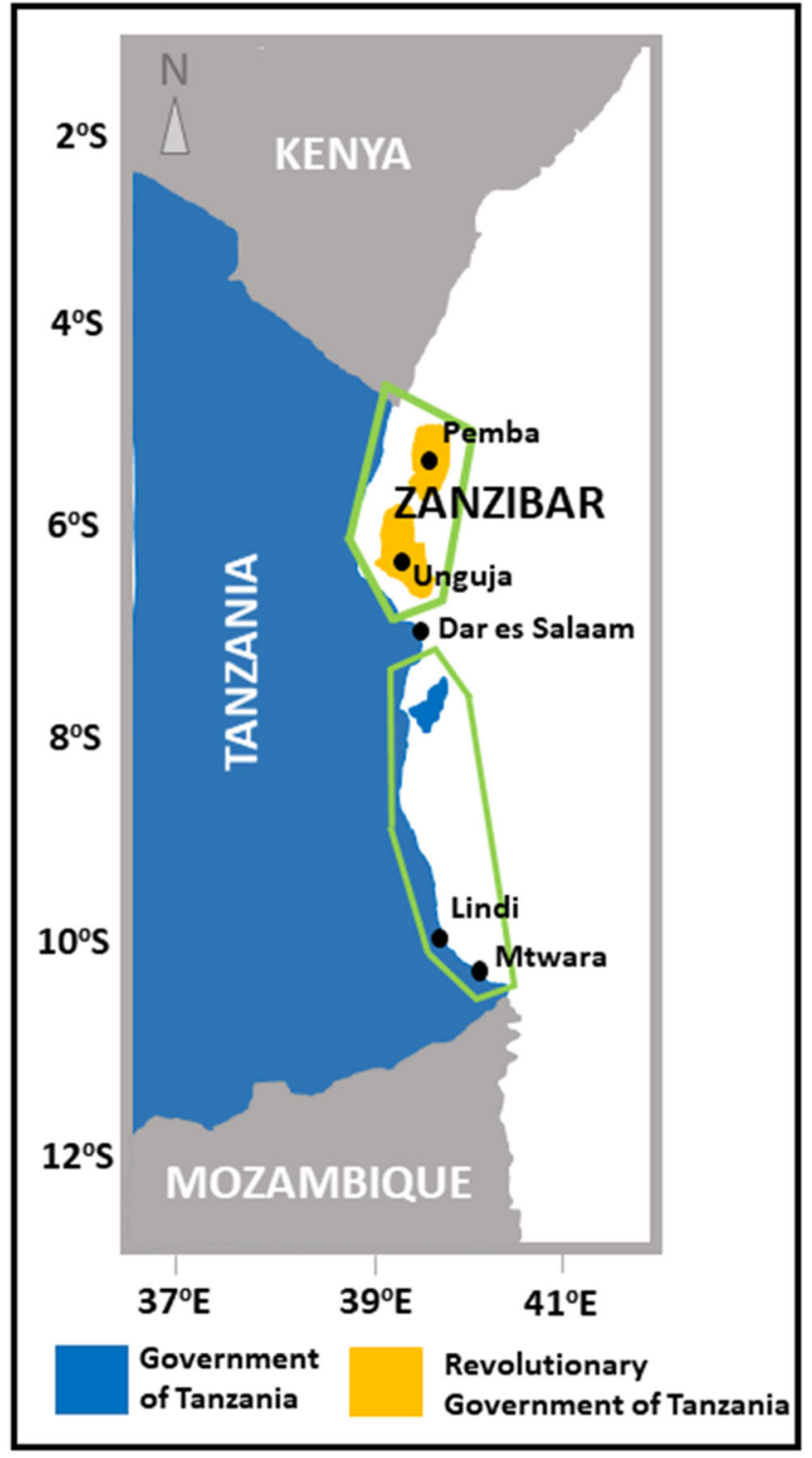

Fig. 1 Map of seaweed cultivation areas (highlighted in green), with survey sample locations Pemba, Unguja, Lindi and Mtwara, plus the main trading port Dares Salaam

policy strategy is expected to be developed in the coming years, with the seaweed sub-sector a component of this broad-scale strategy (GoT 2018). The objective of this policy strategy is to align the seaweed industry with the Tanzanian poverty alleviation strategy (2010-2020); the Tanzania Development Vision 2020; the Zanzibar Vision 2020; and the United Nations Millennium Sustainable Development Goals. In addition, it aims to provide support for the seaweed farmers to access appropriate farming equipment and propagules, and to promote best practices, such as some aspects of biosecurity (GoT 2010a; 2015b).

The aim of this study was to identify biosecurity capacity in existing legislation, policies and guidelines-herein collectively known as biosecurity frameworks - which are relevant to the seaweed industry in Tanzania (both mainland and Zanzibar). This analysis identified the biosecurity themes and already included risks in existing frameworks, which are of relevance to the national seaweed industry. These results highlight critical gaps in existing national frameworks, and point out where areas of existing capacity could be built on to address the gaps. Finally, recommendations are provided for both governments to inform the future development of a coherent biosecurity strategy for seaweed cultivation, limit the impact of diseases and pests, and support a sustainable national industry.

\section{Materials and methods}

Selected biosecurity legislation, policies and guidelines (collectively known as frameworks) were identified through a thorough review of both published and grey literature. The frameworks were chosen for their relevance to biosecurity and seaweed farming in Tanzania. Texts of frameworks were obtained from either government websites or directly from government offices (both GoT and RGoZ) including the Ministry of Natural Resource and Tourism, Ministry of Livestock and Fisheries (Fisheries division), National Environmental Management Council and Seaweed Cluster Initiative Office. The texts of frameworks were comparatively analysed using methods adapted from Dahlstrom et al. (2011) and using the FAO biosecurity toolkit guidelines (FAO 2007). The biosecurity content of the framework texts was analysed in the context of the national seaweed farming industry in Tanzania.

\section{Thematic analysis}

In order to understand the scope and objectives of selected biosecurity frameworks, five "themes" were analysed based on methods used by Campbell et al. (2019a) and Kambey et al. (2020). The themes included the force of the framework, the terminology used for the inclusion of seaweed aquaculture, the approach taken to implement biosecurity measures, the information type used to inform the text and the inclusion of the precautionary approach.

\section{Inclusion of biosecurity risks in texts of frameworks}

The biosecurity risks associated with seaweed farming in Tanzania were identified in the framework texts, using a list of categorised risks, as listed in Campbell et al. (2019a) and Kambey et al. (2020). Risks were identified in texts of the frameworks, and quantified under five categories including ecological, environmental, ecosystem, economic, social and farmer welfare. 


\section{National biosecurity strategy component analysis}

Using the methods in Kambey et al. (2020), sixteen possible components of a national biosecurity strategy were used to analyse the selected frameworks for the Tanzanian seaweed industry. Each of the components were identified in the texts and quantified to understand their use in current prominence in national biosecurity strategy.

\section{Results}

Thirteen frameworks were selected for analysis based on their inclusion of the biosecurity concept and/or their relevance to the seaweed aquaculture industry in Tanzania. Eight of these frameworks are implemented by the GoT across the mainland, and the remainder are implemented by the RGoZ across Zanzibar (Table 1). These frameworks were then systematically analysed for general biosecurity themes, inclusion of specific biosecurity risks and the relevant components of a national biosecurity strategy. Eight frameworks implemented by GoT on the mainland focus mainly on the improvement of seaweed farming and production, increasing the production of the higher valued $K$. alvarezii and $K$. striatus, safeguarding indigenous fauna and flora, protecting habitats and addressing environmental issues such as pollution. The remaining five frameworks implemented by RGoZ across Zanzibar aim to promote research into the causes of diseases, the effects of epiphytes on seaweed, adaptation of cultivation to move into deeper water in order to cultivate in cooler water to mitigate disease and epiphyte outbreaks, and improvements to farm infrastructure to avoid seaweed breakage and loss in rough weather conditions.

\section{Thematic analysis}

Thematic analysis of the frameworks showed that only $31 \%$ were legally binding (Table 1 ). Seaweed aquaculture was explicitly mentioned in $69 \%$ of the frameworks, while the remaining referred to all aquaculture and fisheries activities in general terms. The Environmental Management Act (GoT 2004) included information regarding only general aspects of biosecurity, but is not specific to seaweed. More specific biosecurity approaches relating to disease prevention or control measures were mentioned in $31 \%$ of the frameworks. The Environmental Management Act (GoT 2004) included penalties in their approach to preventing the introduction of poisonous or pollutant material to the aquatic environment. None of the frameworks analysed explicitly mentioned the use of precaution in measures to minimise the risk of introducing pests and/or diseases to a seaweed cultivation region or site. Four of the frameworks (31\%) explicitly included the precautionary approach to minimise the introduction of invasive species, while the remaining frameworks did not mention any precautionary biosecurity measures.

\section{Inclusion of biosecurity risks in texts of frameworks}

Thirty-five possible risks posed as a result of pests, diseases and non-native species, as used in an analysis by Kambey et al. (2020), were grouped into five categories that included wider environmental impacts, changes in ecological interactions, impacts on ecosystem processes, economic impacts to the farm, societal impacts and direct impacts on farm workers welfare (Table 2). Out of the 35 identified risks, only six (17\%) were specifically included across five of the thirteen frameworks. Habitat loss was included in both the Tanzania Mariculture Guidelines Sourcebook (GoT 2001) and Seaweed Strategic Development Plan (GoT 2005). The introduction of toxicity to the environment was included in the Environmental Management Act (GoT 2004). Changes in ecological interactions through herbivory were included in the Seaweed Strategic Development Plan (GoT 2005). Production loss due to pests and diseases was included in the Zanzibar Research Agenda (RGoZ 2015). Loss of income due to the effects of pests and diseases was included in the Seaweed Cluster Initiative (Msuya, 2006). The communication of biosecurity risks with farmers was included in the ZaSCI (2006), specifically through epidermal reactions to the "ice-ice" disease. Out of the total risks, $28(83 \%)$ were not included in the selected biosecurity frameworks.

\section{National biosecurity strategy component analysis}

Sixteen components of a national biosecurity strategy, used in the analysis of Indonesian frameworks by Kambey et al. (2020), were identified in the thirteen possible frameworks from Tanzania (Table 3). Four biosecurity components $(25 \%)$ were identified in two of the frameworks; these included regulations on transport or movement of seaweed, regulations concerning introduction of exotic seaweed species, quarantine measures established for imported seaweed and import regulations related to the introduction of diseases. These components were each identified in the RGoZ (2010) and GoT (2003b). Both frameworks stipulate that: "any introduced aquatic species should get a permit so as to safeguard indigenous fauna and flora, protect habitat and protection of animals, plants and human diseases" (GoT 2003b; RGoZ 2010). The remaining 11 frameworks did not explicitly include any of the listed national biosecurity components in their texts. 
Table 1 Frameworks identified related to biosecurity and/ or the seaweed farming industry in Tanzania

\begin{tabular}{|c|c|c|c|c|c|c|}
\hline Framework & $\begin{array}{l}\text { Relevant } \\
\text { region* }\end{array}$ & $\begin{array}{l}\text { Force of } \\
\text { framework }\end{array}$ & $\begin{array}{l}\text { Inclusion of } \\
\text { seaweed }\end{array}$ & $\begin{array}{l}\text { Biosecurity } \\
\text { approach }\end{array}$ & $\begin{array}{l}\text { Information type } \\
\text { used }\end{array}$ & $\begin{array}{l}\text { Use of } \\
\text { precaution }\end{array}$ \\
\hline $\begin{array}{l}\text { Tanzania Mariculture Guidelines Source Book } \\
\text { (GoT 2001) }\end{array}$ & $\mathrm{TZ}$ & Not binding & Explicit & None & None & No \\
\hline $\begin{array}{l}\text { Fisheries Act No. } 22 \text { of 2003, Tanzania (GoT } \\
\text { 2003b) }\end{array}$ & $\mathrm{TZ}$ & Binding & Not explicit & Prevention & Expert opinion & Yes explicit \\
\hline Environmental Management Act (GoT 2004) & $\mathrm{TZ}$ & Binding & Not explicit & Penalties & Expert opinion & Yes explicit \\
\hline Seaweed strategic development plan (GoT 2005) & $\mathrm{TZ}$ & Not binding & Explicit & None & Experience-based & No \\
\hline Seaweed Cluster Initiative (2006) & ZNZ & Not binding & Explicit & None & Experience based & No \\
\hline $\begin{array}{l}\text { Tanzania National Research and Development } \\
\text { Policy (GoT 2010b) }\end{array}$ & $\mathrm{TZ}$ & Not binding & Explicit & None & None & No \\
\hline Fisheries Act No. 7 of 2010 (GoT 2010a) & $\mathrm{ZNZ}$ & Binding & Not explicit & Prevention & Expert opinion & Yes explicit \\
\hline $\begin{array}{l}\text { Zanzibar Agricultural Transformation Initiative } \\
\text { (RGovZ 2010) }\end{array}$ & $\mathrm{ZNZ}$ & Not binding & Explicit & None & None & No \\
\hline $\begin{array}{l}\text { Aquaculture Development Strategy and Plan of } \\
\text { (RGovZ 2014) }\end{array}$ & $\mathrm{ZNZ}$ & Not binding & Explicit & None & None & No \\
\hline National Fisheries Policy of Tanzania (GoT 2015) & $\mathrm{TZ}$ & Binding & Not explicit & Prevention & Expert opinion & Yes explicit \\
\hline $\begin{array}{l}\text { Tanzania Research Agenda (Priorities) } \\
\quad(2016-2020) \text { (GoT 2016) }\end{array}$ & $\mathrm{TZ}$ & Not binding & Explicit & None & None & No \\
\hline $\begin{array}{l}\text { Zanzibar Research Agenda (2015-2020) (RGoZ } \\
\text { 2015) }\end{array}$ & $\mathrm{ZNZ}$ & Not binding & Explicit & None & None & No \\
\hline $\begin{array}{l}\text { Tanzania Aquaculture Development Strategy } \\
\text { (GoT 2018) }\end{array}$ & $\mathrm{TZ}$ & Not binding & Explicit & None & None & No \\
\hline
\end{tabular}

TZ, Tanzania mainland; ZNZ, Zanzibar (including the islands of Unguja and Pemba)

\section{Discussion}

Biosecurity is an important aspect in managing crop loss, food insecurity and loss of community livelihood. In agriculture, it has been estimated that introductions of plant species across borders may introduce invasive species, which in 2003 was estimated to account for losses of approximately US\$ 400 billion globally (Desonie 2007). Although published reports of diseases and pests in seaweed aquaculture are numerous (Ward et al. 2019), management strategies included in policies to implement biosecurity in the seaweed industry have remained sparse (Campbell et al. 2019a; Kambey et al. 2020). In Tanzania, biosecurity issues regarding the marine plants have not been integrated into policies and strategies, which although this is in line with other producing countries (Kambey et al. 2020; Mateo et al. 2020), if improved could result in practices which help safeguard the Tanzanian seaweed industry.

\section{Current status of biosecurity frameworks available to the seaweed industry in Tanzania}

The frameworks identified in the current study are divided according to which part of the Tanzanian Republic they belonged to, i.e. mainland or Zanzibar. There was no framework identified which was applicable to both mainland and Zanzibar explicitly. This is a result of two operating governments: one for the union (the Government of Tanzania, GoT) and one for Zanzibar (Revolutionary Government of Zanzibar, RGoZ). This is an important aspect for the development of a national biosecurity strategy for an industry, which geographically spans both areas (Fig. 1). Not only do farms exist across these regions, but the industry is actively trading, moving and managing crop and produce between them (Msuya pers. comm), which means protocols for both governments should be aligned and a clear communication plan put in place. One solution to developing frameworks for the seaweed industry could be to take an "adaptive governance" approach to biosecurity, where the spatial difference is embraced by continued devolved and regional management. Using this approach, the geographical distance to industry is minimised, communication paths are shorter, meaning miscommunication is minimised, and alignment is achieved through agreements between the devolved governments (Cook et al. 2010).

In addition to the geographical separation of frameworks, none of the binding frameworks was found to specifically include seaweed, and most were outdated with dates ranging as far back as 2001. Any seaweed-specific (at least mentioning seaweed) frameworks were non-binding, and were developed by organisations other than the governmental departments (mostly NGOs, academia or donor-funded projects). As a 


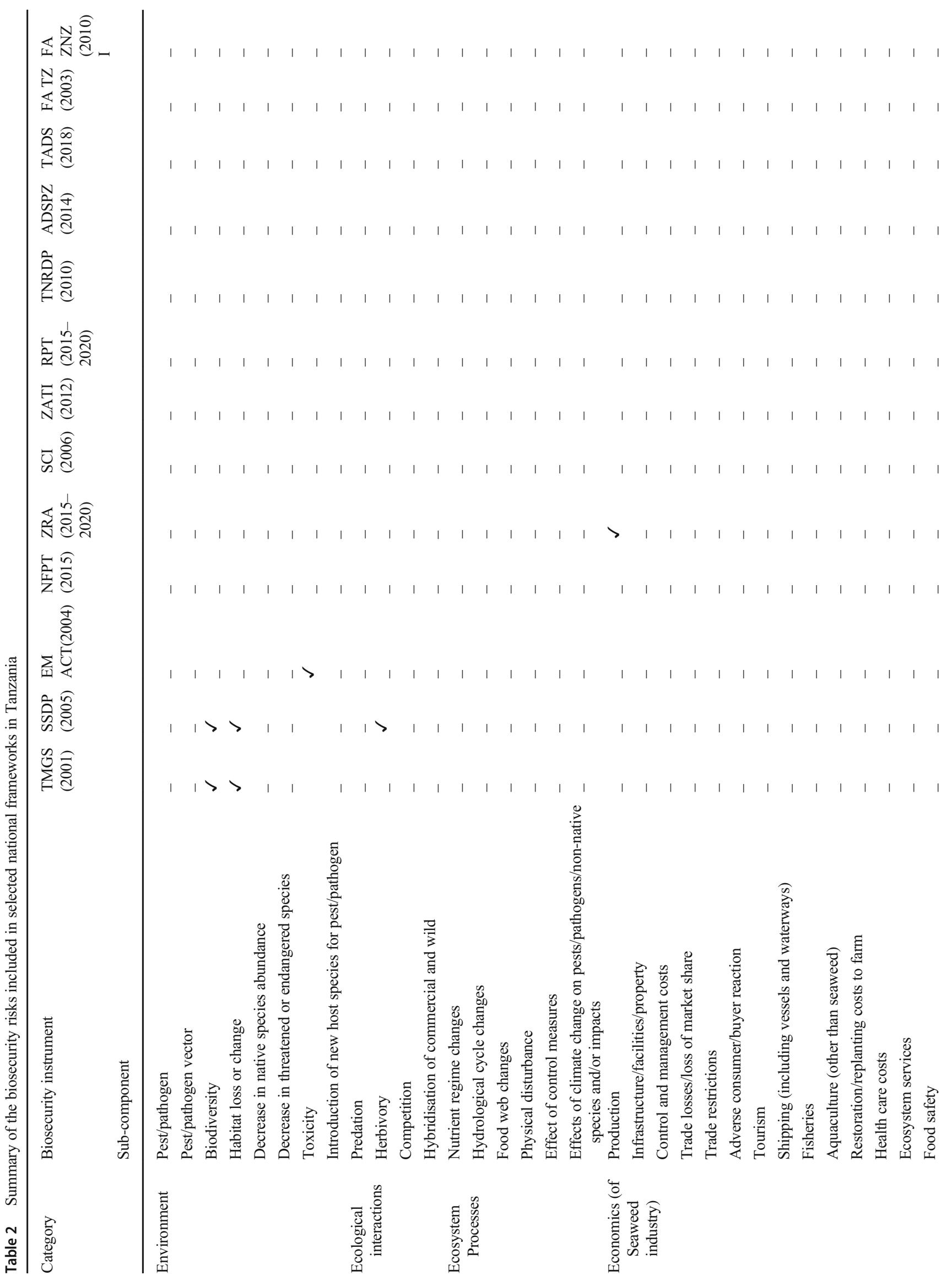


result, there are no clearly defined, or practically implementable, measures for controlling diseases on seaweed farms under either the GoT or RGoZ governments. However, through research projects and communication of farmers' knowledge through co-operatives, different measures to control diseases of farmed seaweeds have been informally practiced (e.g. moving into deeper water, placing farms near seagrass beds where there are higher nutrients and visual health checks of planted propagules) (Largo et al. 2020). This small-scale action is only available to farmers directly involved in research or capacity building projects, such as the SeaPoWer initiative (Brugere et al. 2020), which provided farmers with an opportunity to learn how to use tubular netting in deeper water where crop health is less affected. Continued small-scale and short-term funded action is limited, though in its effect on a larger regional or national-scale without the support of governmental frameworks to mandate such changes.

Even in the case of the national biosecurity strategy established to control the introduction and export of plants, which includes "aquatic flora" (seaweeds), seaweed farmers continue to transfer crops from one region to another without considering the existing regulations, showing that, even in the case of a regulated measure for control, without the buy-in from the industry practitioners to protect themselves from such impacts, policies can remain unsuccessful. Therefore, without the involvement of farmers, processors, buyers and exporters in the development of an adaptive governance approach to biosecurity, there will be little incentive for implementation on a national scale (Cook et al. 2010; Reed and Curzon 2015).

\section{Biosecurity themes in national frameworks}

In Tanzania, legally binding biosecurity regulations for the aquaculture industry are few, and there is a lack of clarity on which ones are required to be implemented by an individual farmer. For example, farmers may plant diseased propagules, and take propagules from one place to another without assessing the disease risk, hence potentially negatively affecting seaweed production (Rusekwa, pers. comm.). The frameworks that mention precautionary approaches to controlling diseases (e.g. import regulations, quarantine measures for aquatic flora, regulations for exotic aquatic flora and regulations on transport or movement of aquatic flora) are not explicit to all farmers, since the word "seaweed" is not mentioned directly in these frameworks, instead the word "aquatic flora" is used. However, the Director of Aquaculture in the Ministry of Fisheries, in collaboration with local authorities, has the mandate to regulate the collection, sale, import and export of aquatic floral products (GoT 2003b; RGoZ 2010). The GoT (2003b) explicitly prohibits the transportation of 
Table 3 Biosecurity components included in national biosecurity frameworks

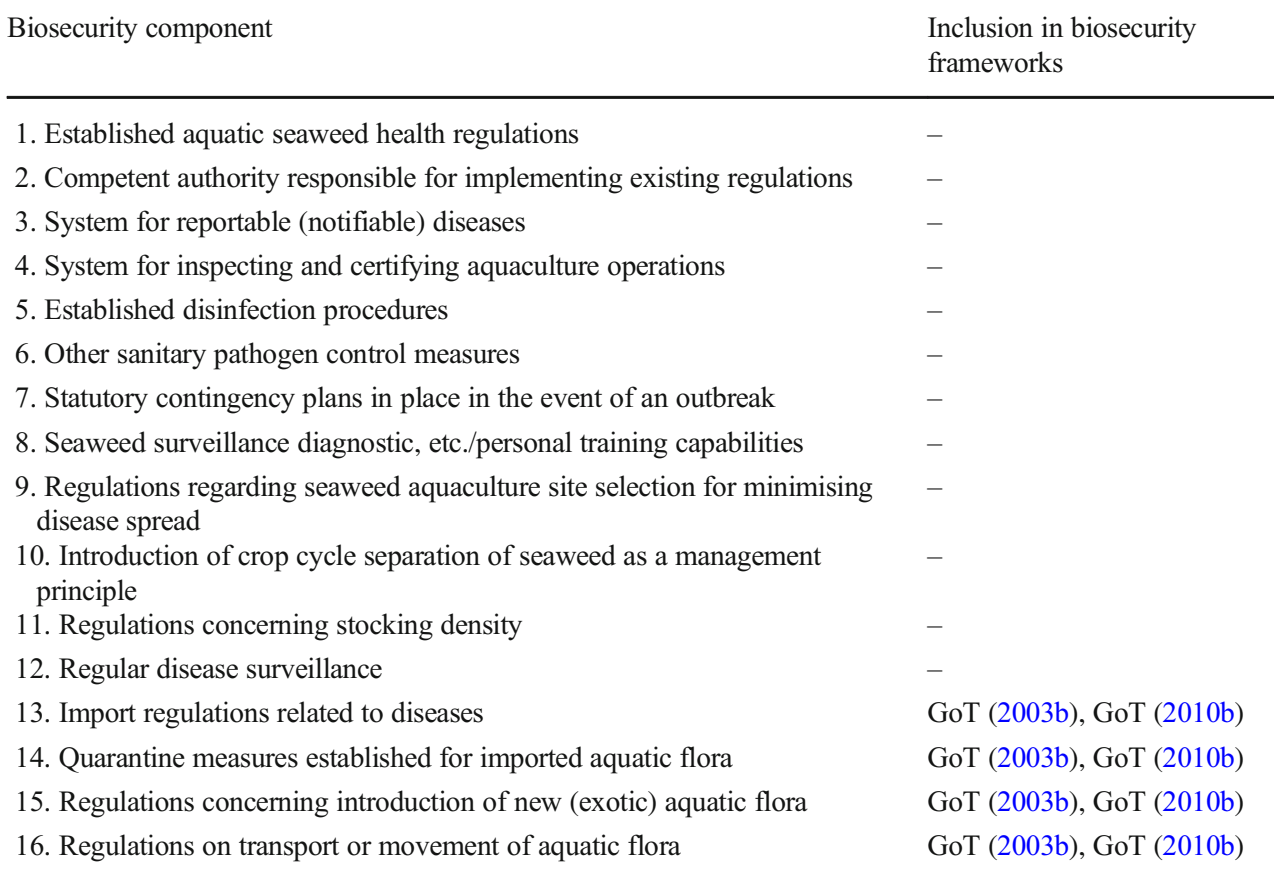

GoT (2003b) Fisheries Act No. 22 Tanzania (2003), GoT (2010b) Fisheries Act No. 7 Zanzibar (2010) seaweeds (defined in the text as aquatic flora) from, or into, the country without permission; therefore, there is an existing tool for controlling the introduction of invasive cultivars, at the point of import. However, as there is no domestic processing industry, the government implements this regulation through the price negotiations between buyers from overseas processing companies who export the seaweed crop, and a portion of the profit is collected from the seaweed farmers during this sale. Although the international buyers also pay a fee to the government during the sale, ultimately the overall price is determined by the buyer. Under this process, the government is aware of what crop is exported, and that the buyer can provide farming materials, including imported propagules from abroad or across regions, as a part of this price negotiation. However, there have been no supporting biosecurity measures introduced by the government to limit the introduction of exotic cultivars. In addition, seaweeds are being transported from one site to another nationally without permission, which also risks the transmission of disease and pests from one area to another, as has been seen across aquaculture sectors globally (Lafferty et al. 2015; Ingle et al. 2018).

Legislations that do not yet exist for the seaweed industry are already in place for some terrestrial agricultural sectors of Tanzania, and include detailed biosecurity legislations for specific crop commodities. For example, regulations for the coffee industry, written by the GoT (2003a), specifically regulated the prevention and control of coffee plant pests and diseases. Another industry-led example is the Sisal Industry Regulation (GoT 2011), which aims to control pests and diseases of the sisal plant and improve seedlings through meristematic tissue culture technology to maintain brood stock quality. A collaborative approach is also taken in the partnership between Australia and ten African countries, including Tanzania, to look at the relationship between plant biosecurity and food security called the Australia-Africa Plant Biosecurity Partnership (AAPBP) (CABI 2017). This is another example where biosecurity is specifically recognised and is being addressed through an international capacity building project. Other sectors, like livestock and human health, already have well-defined biosecurity frameworks and management practices set in place, although end-users do not necessarily know how to effectively put them into practice (Henjewele 2015; Katz and Mramba 2015; GHSA 2016; Msami 2020). Even more advanced biosecurity proposals include the development of an electronic national inventory of dangerous pathogens working with laboratories that deal with "pathogens of concern" (Brizee et al. 2019). Therefore, although the seaweed industry in Tanzania does not yet have specific biosecurity regulations, other industries have already established mechanisms through policy and legislation, which could be reflected in future seaweed policy and legislation.

\section{Biosecurity risks in national frameworks}

The biosecurity risks from pests, diseases and the spread of non-native species in the Tanzanian seaweed industry have been reported in research articles from as early as 1996 
(Msuya et al. 1996; Lyimo et al. 2006, 2008; Zemke-White and Smith 2006; Eklöf et al. 2012), demonstrating recognition of existing biosecurity risks associated with production and processing. However, uptake of any practical management measures for these biosecurity risks remains quite low on a national scale in Tanzania. Biosecurity risks will exist for several actors in the Tanzanian seaweed value chain. For example, farmers and propagule handlers are the most likely to spread diseases and pests, as is seen in the agricultural sectors (FAO 2011). For example, farmers commonly practice the sharing of propagules between farms, villages, districts and even regions (e.g. K. alvarezii seeds from Zanzibar to Songo Songo Island) (Msuya and Porter 2014). In so doing, they may share diseased propagules or facilitate the re-planting of infected seaweed, a mode of transmission already observed elsewhere in the tropical seaweed industry (Hurtado et al. 2017).

Seaweed export companies like Zanzibar Agro-Seaweed Company Ltd. (ZASCOL), Zanzibar East Africa seaweed company (ZANEA) and C-Weed corporation have been attempting to minimise this practice by providing farmers with enough propagules or the required production volumes they buy, and have been importing alternative varieties of $E$. denticulatum, $K$. alvarezii and $K$. striatus from the Philippines when the existing Tanzanian varieties become unproductive (Lirasan and Twide 1993; Mshigeni 1998; Msuya 2005; Msuya et al. 2014; Largo et al. 2020). More recent examples of imported cultivars include the imported Kappaphycus varieties known locally as "Kikorosho" (variety of K. alvarezii) and "Kikarafuu" (K. striatus), and E. denticulatum (known in the Philippines, and thus in Tanzania, as "million million"). These new cultivars used to replace the unproductive varieties of $K$. alvarezii (cottonii) and E. denticulatum (spinosum) have already started to fail due to a complexity of issues including using the same propagules over a long time and climate change-related stress, resulting in a disease-susceptible crop (Hurtado et al. 2006; Vairappan et al. 2008; Hayashi et al. 2010; Msuya 2011b; Msuya and Porter 2014; Mulyaningrum et al. 2019; Ward et al. 2019). Despite the risk of introducing pathogens through such pathways being discussed globally in recent literature (Cottier-Cook et al. 2016; Badis et al. 2019; Campbell et al. $2019 \mathrm{a}, \mathrm{b})$, it remains unclear if quarantine procedures are followed during the importation of seed stock.

It is possible that low-cost biosecurity measures could be effectively applied to minimise and/or eradicate the discussed diseases risks, like those adopted by the milk and meat industries in Kenya, for example, sanitising containers used in transport and processing equipment with soaps and detergents (Nyokabi et al. 2018). In Tanzania, some seaweed farmers have adopted simple biosecurity measures already, such as drying ropes in the sun in-between harvest and re-seeding (Msuya, pers. comm.). However, with so few biosecurity activities being currently practiced on farms nationally, as well as the lack of supporting policies, implementation of such measures could remain difficult. To support farmers through the development of biosecurity in the seaweed industry, national policies that strengthen biosecurity awareness and support farmers to invest in biosecurity practices, could help to build the capacity of both farmers and extension officers, which is essential in a successful national biosecurity strategy (Bondad-Reantaso et al. 2018; Campbell et al. 2019a).

\section{Components of a national biosecurity strategy in Tanzania}

A majority of potential components in a national biosecurity strategy were not identified in existing frameworks (Table 3). The four national biosecurity components identified in existing frameworks for import regulations related to diseases, quarantine measures established for imported aquatic flora, regulations concerning introduction of new (exotic) aquatic flora and regulations on transport or movement of aquatic flora were found in two of the identified frameworks: the Tanzania GoT (2003b) and RGoZ (2010). Although the components were mentioned in these acts, there is very little detail regarding their application in seaweed farming, but rather the general biosecurity approach of the policy. In Tanzania, there is no established regulation for many components considered as key in a strong aquaculture biosecurity strategy: aquatic seaweed health, established disinfection procedures, site selection, monitoring or reporting of diseases and/ or pests (Bondad-Reantaso et al. 2005; Scarfe et al. 2008). There is also a lack of any government-supported procedures for extension officers to inspect or certifying seaweed farm operations, which also exist in other agricultural sectors such as forestry, sisal and coffee, for which there are inspections for the prevention, control and management of known diseases (e.g. GoT 2011, 2013). This type of support has been demonstrated to limit the impact of pests and diseases in other agricultural industries in Australia (Anderson et al. 2017). Currently, the Ministry of Fisheries and Livestock is best placed to establish similar national biosecurity strategies for the seaweed industry, as they already have the capacity for terrestrial crops, which have legally binding biosecurity regulations for importation or export of plants, and disease control and prevention. Without similar support, the impacts of diseases and pests of seaweeds which are affecting the national industry will remain undocumented, and without a strategic plan for limiting future outbreaks.

\section{Conclusions}

In Tanzania, there are existing biosecurity frameworks for aquaculture which are legally binding, but their scope is 
limited to the fish farming industry, and inclusion of farmed seaweeds remains uncertain. The inclusion of biosecurity legislation regarding seaweed farming is lacking nationally, and any known biosecurity measures are currently informally practiced by farmers, which can result in an incoherent approach to managing biosecurity nationally. The Government of Tanzania already has well-established biosecurity policies specific to terrestrial plants (e.g. coffee and sisal), farmed fish and livestock (including piggeries and poultry), which are explicitly tailored to the industries. Such biosecurity frameworks do not exist that solely accommodate the specific challenges the seaweed industry faces. This analysis of existing frameworks also highlights the geographical disconnect between the two governments involved in the Tanzanian seaweed industry, i.e. the United Republic of Tanzania Government and the Revolutionary Government of Zanzibar. Both governments currently lack biosecurity policies, which explicitly cover seaweed farming, despite the industry spanning both administrative jurisdictions. However, both governments are in the process of revising their aquaculture policy strategies to include acts, which will cover seaweed farming and biosecurity more specifically. Therefore, this paper provides timely information on policy gaps and deficiencies to assist both governments in establishing coherent biosecurity policies, which could improve the control of diseases and pests that limit the productivity of the Tanzanian seaweed industry.

Funding information This work is funded by GlobalSeaweedSTAR Project (BB/P027806/1) under the Global Challenges Research Fund, United Kingdom Research and Innovation (UKRI) 2017-2021.

Open Access This article is licensed under a Creative Commons Attribution 4.0 International License, which permits use, sharing, adaptation, distribution and reproduction in any medium or format, as long as you give appropriate credit to the original author(s) and the source, provide a link to the Creative Commons licence, and indicate if changes were made. The images or other third party material in this article are included in the article's Creative Commons licence, unless indicated otherwise in a credit line to the material. If material is not included in the article's Creative Commons licence and your intended use is not permitted by statutory regulation or exceeds the permitted use, you will need to obtain permission directly from the copyright holder. To view a copy of this licence, visit http://creativecommons.org/licenses/by/4.0/.

\section{References}

Anderson C, Low-Choy S, Whittle P, Taylor S, Gambley C, Smith L, Gillespie P, Löcker H, Davis R, Dominiak B (2017) Australian plant biosecurity surveillance systems. Crop Prot 100:8-20

Badis Y, Klochkova TA, Brakel J, Arce P, Ostrowski M, Tringe SG, Kim GH, Gachon CMM (2019) Hidden diversity in the oomycete genus Olpidiopsis is a potential hazard to red algal cultivation and conservation worldwide. Eur J Phycol 55:162-171

Bondad-Reantaso MG, Subasinghe RP, Arthur JR, Ogawa K, Chinabut S, Adlard R, Tan Z, Shariff M (2005) Disease and health management in Asian aquaculture. Vet Parasitol 132:249-272
Bondad-Reantaso MG, Sumption K, Subasinghe R, Lawrence M, Berthe F (2018) Progressive management pathway to improve aquaculture biosecurity (PMP/AB)1. FAO Aquac Newsl 58:9-11

Brizee S, Makondo ZE, Mwikwabe NM (2019) National inventories of dangerous pathogens expert workshops and manual development for inter-regional implementation. Next Generation for Biosecurity in GHSA Competition, 4pp. https://media.nti.org/documents/ Second Place Winner.pdf

Brugere C, Msuya FE, Jiddawi N, Nyonje B, Maly R (2020) Can innovation empower? Reflections on introducing tubular nets to women seaweed farmers in Zanzibar. Gender, Technology and Development. https://doi.org/10.1080/09718524.2019.1695307

CABI (2017) \$1.8 million partnership to improve plant biosecurity in Africa pays dividends. CABI News. 3pp. https://www.cabi.org/ news-article/1-8-million-partnership-to-improve-plant-biosecurityin-africa-pays-dividends/

Cai J, Hishamunda N, Ridler N (2013) Social and economic dimensions of carrageenan seaweed farming: a global synthesis. In: Valderrama D, Cai J, Hishamunda N, Ridler N (eds) Social and economic dimensions of carrageenan seaweed farming. FAO Fisheries and Aquaculture Technical Paper No. 580. FAO, Rome, p 51

Campbell I, Kambey C, Mateo J, Rusekwa SB, Hurtado A, Msuya FE, Cottier-Cook EJ (2019a) Biosecurity policy and legislation for the global seaweed aquaculture industry. J Appl Phycol. https://doi.org/ 10.1007/s10811-019-02010-5

Campbell I, Macleod A, Sahlmann C, Neves L, Funderud J, Øverland M, Hughes AD, Stanley M (2019b) The environmental risks associated with the development of seaweed farming in Europe - prioritizing key knowledge gaps. Front Mar Sci 6:107

Cook DC, Liu S, Murphy B, Lonsdale WM (2010) Adaptive approaches to biosecurity governance. Risk Anal 30:1303-1314

Cottier-Cook EJ, Nagabhatla N, Badis Y, Campbell M, Chopin T, Dai W, Fang J, He P, Hewitt C, Kim GH, Huo Y, Jiang Z, Kema G, Li X, Liu F, Liu H, Lu Q, Luo Q, Mao Y, Msuya FE, Rebours, C, Shen H, Stentiford GD, Yarish C, Wu H, Yang Z, Zhang J, Zhou Y, Gachon CMM (2016) Safeguarding the future of the global seaweed aquaculture industry. United National University (INWEH) and Scottish Association for Marine Science Policy Brief. pp. 1-12.

Dahlstrom A, Hewitt CA, Campbell ML (2011) A review of international, regional and national biosecurity risk assessment frameworks. Mar Policy 35:208-217

Degenhardt S (2015) A multiple-case study of exploring social-ecological resilience of seaweed farming in Unguja. Master Thesis, Norwegian University of Life Sciences.

Department of Marine Resources Zanzibar (2019) Fisheries \& Marine Resources - Ministry of Agriculture, Natural Resources, Livestock and Fisheries, Available at: http://www.kilimoznz.go.tz/fisheries. php.

Desonie D (2007) Biosphere: ecosystems and biodiversity loss. Infobase Publishing, New York

Eklöf JS, Msuya FE, Lyimo TJ, Buriyo AS (2012) Seaweed farming in Chwaka Bay: a sustainable alternative in aquaculture? In: de la Torre-Castro M, Lyimo TJ (eds) People, nature and research in Chwaka Bay, Zanzibar, Tanzania, Zanzibar Town. WIOMSA, Zanzibar, pp 213-233

FAO (2007) Biosecurity toolkit. FAO, Rome, 128 pp.

FAO (2011) A value chain approach to animal diseases risk management -technical foundations and practical framework for field application. Animal Production and Health Guidelines, 1st edn. FAO, Rome

GHSA (2016) GHSA JEE Assessment of the United Republic of Tanzania. 67 pp. Available at:https://ghsaindonesia.files. wordpress.com/2016/02/report-of-ghsa-external assessmenttanzania.pdf.

GoT (1998) The United Republic of Tanzania, plant protection regulation. Available at: http://extwprlegs1.fao.org/docs/pdf/tan19459. pdf. 
GoT (2001) The United Republic of Tanzania. Tanzania mariculture guidelines source book. Tanzania Coastal Management Partnership Support Unit and the Mariculture Working group. Dar es Salaam, Tanzania. 222 pp. Available at: https://www. globalseaweed.org/wp-content/uploads/2019/02/TAN_0046.pdf.

GoT (2003a) The United Republic of Tanzania, coffee industry regülations. 60 pp. Available at: http://extwprlegs1.fao.org/docs/pdf/ $\tan 74810 . p d f$

GoT (2003b) The United Republic of Tanzania Fisheries Act No. 22 of Tanzania. $42 \mathrm{pp}$. Available at:https://www.unodc.org/res/cld/ document/tza/2005/fisheries_regulations_2005_html/FISHERIE S_REGULATIONS_2003_sw.pdf.

GoT (2004) The United Republic of Tanzania. The Environmental Management ACT, 2004. National Environmental Management (NEMC) and local Government Authorities. Dar es Salaam, Tanzania. 158 pp. Available at: http://extwprlegs1.fao.org/docs/ pdf $/ \tan 71740$ a.pdf.

GoT (2005) The United Republic of Tanzania. Seaweed Strategic Development Plan. Ministry of Natural Resource and Tourism. Dar es Salaam, Tanzania. 64 pp. Available at: https://www.crc.uri. edu/download/Seaweed Development Strategic Plan.pdf.

GoT (2010a) The United Republic of Tanzania. The national research and development policy, Ministry of communication, science and technology. 44 pp. Available at: http://www.tzonline.org/pdf/National Research\&DevPolicy.pdf.

GoT (2010b). The United Republic of Tanzania Fisheries Act No. 7 of 2010. 18 pp. Available at. http://extwprlegs1.fao.org/docs/pdf/ $\tan 144312$ a.pdf

GoT (2011) The United Republic of Tanzania. The sisal industry regulations. 48 pp. Available at: https://www.kilimo.go.tz/uploads/ regulations/The Sisal Industry Regulations of 2011.pdf

GoT (2013) The United Republic of Tanzania. National Agriculture policy, Ministry of Agriculture food security and cooperatives. Dar es Salaam, Tanzania. 42 pp. Available at: http://www.faoilo. org/fileadmin/user_upload/fao_ilo/pdf/ICA_MLW_and_TZ/ NATIONAL_AGRICULTURAL_POLICY-2013.pdf.

GoT (2015a) The United Republic of Tanzania. Fisheries Sector Development Programme Ministry of Livestock and Fisheries Development. Dar es Salaam, Tanzania. 45 pp. Available at: http://extwprlegs1.fao.org/docs/pdf/tan168881.pdf.

GoT (2015b) The United Republic of Tanzania. National Fisheries Policy, Ministry of Livestock and Fisheries development. Dar es Salaam, Tanzania. 58 pp. Available at: http://extwprlegs1. fao.org/docs/pdf/tan168881.pdf.

GoT (2016) The United Republic of Tanzania - Research Priorities for Tanzania 2015 - 2020. 33 pp. ISSN 2507-7899

GoT (2018) The United Republic of Tanzania. Tanzania Aquaculture Development Strategy (In Kiswahili), Ministry of livestock and fisheries, Tanzania, $46 \mathrm{pp}$.

Hassan IH, Othman WJ (2019) Seaweed (Mwani) farming as an adaptation strategy to impacts of climate change and variability in Zanzibar. In: Yanda PZ, Bryceson I, Mwevura H, Mung'ong'o CG (eds) Climate change and coastal resources in Tanzania. Springer, Cham, pp 53-68

Hayashi L, Hurtado AQ, Msuya FE, Bleicher-Lhonneur G, Critchley AT (2010) A review of Kappaphycus farming: prospects and constraints. In: Israel A, Einav R, Seckbach J (eds) Seaweeds and their role in globally changing environments. Springer, Dordrecht, pp 251-283

Henjewele CJ (2015) Health risks and biosecurity measures in pig production in urban and peri-urban areas of Morogoro municipality. MSc Thesis, Sokoine University of Agriculture, Tanzania, Tanzania

Hurtado AQ, Critchley AT, Trespoey A, Bleicher-Lhonneur G (2006) Occurrence of Polysiphonia epiphytes in Kappaphycus farms at Calaguas Is., Camarines Norte, Philippines. J Appl Phycol 18: 301-306
Hurtado AQ, Critchley AT, Neish IC (eds) (2017) Tropical seaweed farming trends, problems and opportunities: focus on Kappaphycus and Eucheuma of commerce. Springer, Cham

Ingle KN, Polikovsky M, Chemodanov A, Golberg A (2018) Marine integrated pest management (MIPM) approach for sustainable seagriculture. Algal Res 29:223-232

Kambey CSB, Campbell I, Sondak CFA, Nor ARM, Lim PE, CottierCook EJ (2020) An analysis of the current status and future of biosecurity frameworks for the Indonesian seaweed industry. J Appl Phycol. https://doi.org/10.1007/s10811-019-02020-3

Katz A, Mramba F (2015) Strengthening health and biosecurity in tanzania by biodetection capacity building. BWC Meeting of Experts, Side event on Global Health Security Agenda (GHSA) Geneva. Available at: https://www.unog.ch/80256EDD006B8954/ (httpAssets)/BEDA1821F81E0FF7C1257ED200493537/\$file/ Katz_Mramba_Tanzania_GHSA+side+event_8_11_2015.pdf.

Lafferty KD, Harvell CD, Conrad JM, Friedman CS, Kent ML, Kuris AM, Powell EN, Rondeau D, Saksida SM (2015) Infectious diseases affect marine fisheries and aquaculture economics. Annu Rev. Mar Sci 7:471-496

Largo DB, Msuya FE, Menezes A (2020) Understanding the diseases and die-off of seaweeds in Zanzibar. FAO Fisheries and Aquaculture Technical Paper No. 662. FAO, Rome 56 pp.

Lirasan T, Twide P (1993) Farming Eucheuma in Zanzibar, Tanzania. Hydrobiologia 260:353-355

Lyimo TJ, Mvungi EF, Lugomela C, Björk M (2006) Seagrass biomass and productivity in seaweed and non-seaweed farming areas in the east coast of Zanzibar Tanzania. West Ind Ocean J Mar Sci 5:141-152

Lyimo TJ, Mvungi EF, Mgaya YD (2008) Abundance and diversity of seagrass and macrofauna in the intertidal areas with and without seaweed farming activities in the east coast of Zanzibar. Tanzania J Sci 34:41-51

Mateo JP, Campbell I, Cottier-Cook EJ, Luhan MRJ, Ferriols VMEN, Hurtado AQ (2020) Analysis of biosecurity-related policies governing the seaweed industry in the Philippines. J Appl Phycol. 32:2009-2022

Msami H (2020) Strategies for the prevention and control of infectious diseases (including Highly Pathogenic Avian Influenza) in Eastern Africa. Good biosecurity practices in non integrated commercial and in scavenging production systems in Tanzania. FAO, Rome $28 \mathrm{pp}$. Undated document. Accessed on 28 Feb 2020. Available at: http:// www.fao.org/3/a1839e/al839e00.pdf.

Mshigeni KE (1998) The seaweed resources of Tanzania. In: Critchley AT, Ohno M (eds) Seaweed resources of the world. Japan International Cooperative Agency, Yokosuka, pp 389-397

Msuya FE (2005) Seaweed farming in Tanzania: farming processes and interactions between farmers and other stakeholders. In: Mwamila BLM, Temu AK (eds) Proceedings of national stakeholders workshop on establishment of an innovation systems and clusters programme in Tanzania, Bagamoyo, pp 195-206 Available at: https:// www.researchgate.net/publication/237150087_Seaweed_Farming in_Tanzania_Farming_Processes_and_Interactions_between farmers_and_other_stakeholders

Msuya FE (2006) The seaweed cluster initiative in Zanzibar, Tanzania. In: Mwamila BLM, Temu AK (eds) Proceedings of the 3rd regional conference on innovation systems and innovative clusters in Africa, Dar es Salaam, pp 246-260 Available at: https://www.researchgate. net/publication/237150037_The_Seaweed_Cluster_Initiative_in Zanzibar Tanzania

Msuya FE (2010) Development of seaweed cultivation in Tanzania: the role of the University of Dar es Salaam and other institutions. Aquaculture Compendium. CAB International, Wallingford Available at: https://www.researchgate.net/profile/Flower_Msuya/ publication/237149839_Development_of_seaweed_cultivation_in Tanzania the role of the University of Dar es Salaam and other_institutions/links/0 $/$ deec51c0208510111000000.pdf 
Msuya FE (2011a) The impact of seaweed farming on the socioeconomic status of coastal communities in Zanzibar. Tanzania, J World Aquacult Soc 42:45-48

Msuya FE (2011b) Environmental changes and their impact on seaweed farming in Tanzania. World Aquacult 42:34-37 71

Msuya FE (2012) A study of working conditions in the Zanzibar seaweed farming industry, Women in Informal Employment: Globalizing and Organizing (WIEGO), Cambridge

Msuya FE (2013) Social and economic dimensions of carrageenan seaweed farming in the United Republic of Tanzania. In: Valderrama D, Cai J, Hishamunda N, Ridler N (eds) Social and economic dimensions of carrageenan seaweed farming, Fisheries and Aquaculture Technical Paper No. 580. FAO, Rome, pp 115-146

Msuya FE (2017) Technological development to help women seaweed farmers cope with the effects of climate change in Zanzibar, Tanzania. World Aquaculture 2017:45-47

Msuya FE, Hurtado AQ (2017) The role of women in seaweed aquaculture in the Western Indian Ocean and South-East Asia. Eur J Phycol 52:482-494

Msuya FE, Porter M (2014) Impact of environmental changes on farmed seaweed and farmers: the case of Songo Songo Island, Tanzania. J Appl Phycol 26:2135-2141

Msuya FE, Buriyo A, Omar I, Pascal B, Narrain K, Ravina JJM, Mrabu E, Wakibia JG (2014) Cultivation and utilization of red seaweeds in the Western Indian Ocean (WIO) Region. J Appl Phycol 26:699705

Msuya FE, Ngoile MAK, Shunula JP (1996) The impact of seaweed farming on the macrophytes and macrobenthos of the East Coast of Unguja Island, Zanzibar, Tanzania. Report submitted to the Canadian International Development Agency (CIDA), Institute of Marine Sciences, University of Dares Salaam, Zanzibar, Tanzania, IMS 1997/05, 68 pp.

Mulyaningrum SRH, Suwoyo HS, Paena M, Tampangallo BR (2019) Epiphyte identification on Kappaphycus alvarezii seaweed farming area in Arungkeke Waters, Jeneponto and the effect on carrageenan quality. Indones J Mar Sci 24:146-152

Nyokabi S, Birner R, Bett B, Isuyi L, Grace D, Güttler D, Lindahl J (2018) Informal value chain actors' knowledge and perceptions about zoonotic diseases and biosecurity in Kenya and the importance for food safety and public health. Trop Anim Health Prod 50:509-518

Reed MS, Curzon R (2015) Stakeholder mapping for the governance of biosecurity: a literature review. J Integr Environ Sci 12:15-38

RGoZ (2010) Revolutionary government of Zanzibar, Fisheries Act No. 7 of $201016 \mathrm{pp}$. Available at: https://rade.business.go.tz/media/ The $\% 20$ fisheries $\% 2 \mathrm{https}: / /$ trade.business.go.tz/media/The\% 20fisheries\%20Act, \%202,010.pdf.
RGovZ (2010). Zanzibar agricultural transformation for sustainable development, 2010 - 2020. The Revolutionary Government of Zanzibar. 48 pp. Available at: https://www.gafspfund.org/sites/ default/files/inline-files/ATI.pdf

RGovZ (2014) Zanzibar aquaculture development strategy and action plan. The Revolutionary Government of Zanzibar. FAO TCP/ URT/3401 (ICM). 36pp

RGoZ (2015) Zanzibar research agenda, 2015-2020. The Revolutionary Government of Zanzibar. Commission for Science and Technology (COSTECH), Dar es Salaam. 124 pp. Available at: https://www. c o s t e c h.or.tz/s torage/ u p 1 o a d s / K6D5phV5pOV5gWJ2sLChJWXXo4s5HnEr1Uu0fZdE.pdf.

Rodgers CJ, Carnegie RB, Chavez-Sanchez MC, Martinez-Chavez CC, Furones Nozal MD, Hine PM (2015) Legislative and regulatory aspect of molluscan health management. J Invert Path 131:242-255

Scarfe AD, Lee CS, O’Bryen PJ (2008) Aquaculture biosecurity: prevention, control, and eradication of aquatic animal disease. Wiley, New York

Stentiford DG, Sritunyalucksana K, Flegel TW, Williams BAP, Withyachumnarnkul B, Itsathitphaisarn O, Bass D (2017) New paradigms to help solve the global aquaculture disease crisis. PLoS Pathog 13:e1006160

Vairappan CS, Chung CS, Hurtado AQ, Msuya FE, Bleicher-Lhonneur G, Critchley A (2008) Distribution and symptoms of epiphyte infection in major carrageenophyte-producing farms. J Appl Phycol 20: $477-483$

Valderrama D, Cai J, Hishamunda N, Ridler N (2013) Social and economic dimensions of carrageenan seaweed farming. Fisheries and Aquaculture Technical Paper No. 580. FAO, Rome.

Valderrama J, Cai N, Hishamunda N, Reidler N, Neish IC, Hurtado AQ, Msuya FE, Krishnan R, Narayanakumar M, Kronen D, Robledo E, Gasca-Leyva E, Fraga J (2015) The economics of Kappaphycus seaweed cultivation in developing countries: a comparative analysis of farming systems. Aquacult Econ Manag 19:251-277

Ward GM, Faisan JP, Cottier-Cook EJ, Gachon C, Hurtado AQ, Lim PE, Matoju I, Msuya FE, Bass D, Brodie J (2019) A review of reported seaweed diseases and pests in aquaculture in Asia. J World Aquacult Soc. https://doi.org/10.1111/jwas.12649

Zemke-White WL, Smith JE (2006) Environmental impacts of seaweed farming in the tropics. In: Critchley AT, Ohno M, Largo DB (eds) World seaweed resources: an authoritative reference system. ETI Bioinformatics, Amsterdam

Publisher's note Springer Nature remains neutral with regard to jurisdictional claims in published maps and institutional affiliations. 